\title{
Electrical conductivity and accelerated aging in amaranth (Amaranthus crueentus L.) seeds ${ }^{1}$
}

\author{
Thaís D’Avila Rosa ${ }^{2}$, Ariele Paula Nadal ${ }^{2}$, Henrique Roberto Maldaner ${ }^{2}$, \\ Vanessa Nogueira Soares ${ }^{2}$, Gizele Ingrid Gadotti ${ }^{2 *}$, Francisco Amaral Villela ${ }^{2}$
}

\begin{abstract}
The objective of this study was to determine adequate conditions of water volume, seed quantity and immersion period to perform the electrical conductivity test, and to analyze the parameters of the accelerated aging test and its correlation with the the physiological potential of amaranth seeds. Five lots of amaranth seeds (Amaranthus cruentus), cultivar BRS Alegria, were used. The initial evaluation of the quality of these lots comprehended the following tests: water content, germination, first germination count, accelerated aging (traditional method, and modified versions, using unsaturated and saturated saline solution for the periods of 24,48 and $72 \mathrm{~h}$ ), electrical conductivity in different periods (2, 4, 6, 8 and $24 \mathrm{~h})$, different quantities of water $(25,50$ and $75 \mathrm{~mL})$, different seed quantities (100 and 150), and field emergence. It could be concluded that the accelerated aging test at $41{ }^{\circ} \mathrm{C}$, for $72 \mathrm{~h}$, using unsaturated $\mathrm{NaCl}$ solution was efficient in the classification of amaranth seed lots in levels of vigor. The electrical conductivity test performed for 8 hours with $25 \mathrm{~mL}$ of water and 100 seeds was efficient in the classification of amaranth seeds as to their physiological potential.
\end{abstract}

Index terms: Amaranthus cruentus, solutes leaching, $\mathrm{NaCl}$ solution, germination, vigor.

\section{Condutividade elétrica e envelhecimento acelerado em sementes de amaranto (Amarantus cruentus L.)}

\begin{abstract}
RESUMO - O presente trabalho teve o objetivo determinar as condições adequadas para condução dos testes de condutividade elétrica e de envelhecimento acelerado, e sua correlação na avaliação do potencial fisiológico de sementes de amaranto. Foram utilizados cinco lotes de sementes de amaranto (Amaranthus cruentus), cultivar BRS Alegria. A avaliação da qualidade inicial desses lotes constituiu-se na determinação do teor de água e nos testes de germinação, primeira contagem de germinação, envelhecimento acelerado tradicional e modificado (solução salina não saturada e saturada) empregando-se os períodos de 24 , 48 e $72 \mathrm{~h}$, condutividade elétrica em cinco períodos (2, 4, 6, 8 e 24 h), três quantidades de água ( 25,50 e $75 \mathrm{~mL})$ e dois números de sementes (100 e 150) e emergência em campo. Pode-se concluir que o teste de envelhecimento acelerado a $41^{\circ} \mathrm{C}$ no período de 72 h com uso de solução salina não saturada de $\mathrm{NaCl}$ é eficiente na classificação de lotes de sementes de amaranto, em níveis de vigor. $\mathrm{O}$ teste de condutividade elétrica conduzido no período de oito horas com $25 \mathrm{~mL}$ de água e 100 sementes possibilita a classificação de lotes de sementes de amaranto quanto ao potencial fisiológico.
\end{abstract}

Termos para indexação: Amaranthus cruentus, lixiviação de solutos, solução salina, germinação, vigor.

\section{Introduction}

Pseudocereals, whose seeds are rich in proteins and carbohydrates, have been source of food over time (Casini and La Rocca, 2014), especially for low-income population, like indigenous peoples.
Among the species that belong to the group of pseudocereals, quinoa (Chenopodium quinoa Willd.), buckwheat (Fagopyrum esculentum Moench.), and amaranth (Amaranthus sp.) are some of the most notable ones, and the latter has been praised due to its nutritional composition. Although still little explored, amaranth stands out for its

${ }^{1}$ Submitted on $07 / 24 / 2017$. Accepted for publication on 11/16/2017.

${ }^{2}$ Departamento de Ciência e Tecnologia de Sementes, Universidade Federal de Pelotas, Caixa Postal 354, 96010-900 - Pelotas, RS, Brasil.

${ }^{*}$ Correspondig author $<$ gizele.gadotti@ufpel.edu.br> 
versatility and adaptability to the most varied environments, in comparison to its place of origin, and also for its contribution in food supplementation, both human and animal.

Since cultivation is expanding and there is a scarcity of methodology for evaluating the physiological potential of amaranth seeds, improving and adjusting the methods of determination of vigor are of fundamental importance.

The exploitation of a culture that is still not very common in a particular production system requires numerous evaluations in order to gather as much information as necessary for its cultivation. The germination test, despite providing subsidies to measure the conditions of a seed lot, becomes peculiar to measure the actual capacity of a seed, and to express its maximum potential. Therefore, more concise tests are required in order to submit seeds to adverse conditions, and vigor tests is the most adequate for this purpose, and to provide complementary information to the germination test (Lopes and Franke, 2010).

Given the importance of knowing the vigor of a lot of seeds, more and more requirements are established, both by companies and buyers, regarding the reliability of this information. In addition to the accuracy of the data, the demands also include the time necessary to obtain the information, shorter request time, and additional care, factors that influence the choosing of the most appropriate test to be applied. Among these, the electrical conductivity test, recommended for pea seeds and suggested for soybeans by the Association of Official Seed Analysts (AOSA, 2002), and the accelerated aging test can be mentioned. Although there are no standards for vigor tests in Brazil, according to the International Rules (ISTA, 2014), there are standardized tests, of which it is possible to highlight the accelerated aging and mass electrical conductivity tests for beans, soybean and pea cultures; controlled deterioration test for brassicas and primary root length for maize crops.

The accelerated aging test is a vigor test commonly used to obtain information on the storage capacity of a seed lot, as well as on seedling emergence in a cultivation system (TeKrony, 1995). Thus, this test can be considered one of the most adequate to estimate seed vigor (Marcos-Filho, 1999). This is supported by many related works, as reported for radish (Avila et al., 2006), wheat (Ohlson et al., 2010), beans (Bertolin et al., 2011), lettuce and chicory (Santos et al., 2011).

The electrical conductivity test was performed in several crops, such as pepper (Vidigal et al., 2008), jatropha (Araujo et al., 2012), mung beans (Araujo et al., 2012), eggplant (Alves et al., 2012), and canola (Milani and Lopes, 2015). In these studies, the period of hydration of seeds and the amount of water used were also tested. These parameters are essential, so the test can better suit a particular crop, especially when information is scarce, as in amaranth culture.

Therefore, the aim of this work was to determine the appropriate conditions to perform the electrical conductivity and the accelerated aging tests on amaranth seeds, and to establish the correlation with the emergence test in bed.

\section{Material and Methods}

The experiment was carried out at the Laboratory of Seed Analysis, Department of Plant Sciences, Universidade Federal de Pelotas. Samples of five lots of amaranth seeds (Amaranthus cruentus L.) with different physiological quality (L1, L2, L3, L4 and L5) were used.

Moisture content: it was determined in two replications of $5 \mathrm{~g}$ each, by using the oven method at $105 \pm 3{ }^{\circ} \mathrm{C}$ for 24 hours. Then, the moisture content was calculated by mass difference, based on the wet mass of seeds, according to the Rules for Seed Testing (Brasil, 2009).

Germination: four subsamples of 50 seeds of each lot were used. The seeds were distributed on two towel paper sheets, moistened with a quantity of distilled water equivalent to 2.5 times the weight of the dry substrate, and left to germinate at constant temperature of $25^{\circ} \mathrm{C}$ in the presence of light. The evaluation was performed 14 days after sowing (Brasil, 2009). The results were expressed as percentage of normal seedlings.

First germination count: it was performed together with the germination test, and evaluated on the fifth day after sowing.

Seedlings emergence: four subsamples of 50 seeds were used. They were distributed in furrows of $5.0 \times 1.2 \times 0.9 \mathrm{~m}$ of length, width and depth, respectively, each filled with soil collected from an A1 horizon of a Solodic Eutrophic Haplic Planosol in the region of Pelotas, state of Rio Grande do $\mathrm{Sul}$, Brazil. The seeds were sown at $2 \mathrm{~cm}$ deep and manually irrigated until humidity reached $60 \%$ of field capacity. A single count was performed after 14 days, considering the percentage of emerged seedlings.

Electrical conductivity: it was used the mass method (AOSA, 2002). Four subsamples of 100 to 150 seeds from each lot (without visually detected damage), were previously weighed in analytical precision scale $(0.001 \mathrm{~g})$. As for the water volume, 25,50 and $75 \mathrm{~mL}$ were used, and different hydration periods (2, $4,6,8$ and 24 hours) were established. Seeds immersed in water remained in a BOD incubator at $20{ }^{\circ} \mathrm{C}$ during all periods. Then, the electrical conductivity was measured with a conductivity meter, and the results were expressed in $\mu \mathrm{S} . \mathrm{cm}^{-1} \cdot \mathrm{g}^{-1}$ of seeds.

Accelerated aging: it was carried out using transparent plastic boxes $(11.5 \times 11.5 \times 3.5 \mathrm{~cm})$ with individual 
compartments (minichambers), and internal supports to hold a metallic screen, which was covered with voile fabric to prevent seeds from touching the water, because of their small size. On the screen surface, after weighing (approximately $1.5 \mathrm{~g}$ ), seeds were distributed so as to form a uniform layer. To conduct the accelerated aging test, the following were added to the bottom of each plastic box: a) $40 \mathrm{~mL}$ of distilled water (traditional aging - TRAD); b) $40 \mathrm{~mL}$ of dilute $\mathrm{NaCl}$ solution (11 g of $\mathrm{NaCl}$ per $100 \mathrm{~mL}$ of water) (aging with unsaturated $\mathrm{NaCl}$ solution - USS) and c) $40 \mathrm{~mL}$ of saturated $\mathrm{NaCl}$ solution (40 $\mathrm{g}$ of $\mathrm{NaCl}$ per $100 \mathrm{~mL}$ of water) (aging with saturated $\mathrm{NaCl}$ SSS solution), Avila et al. (2006). The boxes were maintained at $41{ }^{\circ} \mathrm{C}$ for 24,48 , and 72 hours, and then, the germination test was set up as previously described, and the seedlings count was performed on the fifth day.

Seed water content: it was determined according to Brasil (2009). The oven method was used with temperature regulated at $105 \pm 3{ }^{\circ} \mathrm{C}$. For this test, two $5.0 \mathrm{~g}$ subsamples were used, each packed in aluminum containers with lid. The containers were previously dried for one hour in oven at $130{ }^{\circ} \mathrm{C}$, and then cooled down in desiccator containing silica gel. After drying, the containers were weighed with their respective lids. The seeds were put inside the containers to obtain the wet weight (container weight + seed weight). The containers were placed in oven at $105 \pm 3{ }^{\circ} \mathrm{C}$ for $24 \mathrm{~h}$. After, they were taken from the oven, they were let to cool in desiccator, and then were weighed again to obtain the dry weight of the seeds. The results were expressed as a percentage, and the water content (\%) was calculated by multiplying the wet weight (container weight plus wet seed weight) subtracted from the dry weight (container weight plus dry seed weight), divided by the result of the subtraction of the wet weight (container weight plus wet seed weight) by the weight of the container with its lid. The final result was multiplied by 100 .

Experimental design and statistical analyses: a completely randomized design with four replications was used, and the data obtained in each test were submitted to analysis of variance and least significant difference tests, to comparison between the means of the lots by Tukey's test at $5 \%$ probability, and to simple linear correlation by the Pearson's test, for the key variables. The data expressed in percentage were submitted to transformation by the function $\arcsin \mathrm{x} / 100$. The software WinStat (Machado and Conceição, 2007) was used to perform the statistical analyses.

\section{Results and Discussion}

Data on water content of the amaranth seeds, initially and after each accelerated aging period, in the traditional and in the modified methods (using $11 \%$ unsaturated $\mathrm{NaCl}$ solution and $40 \%$ saturated saline $\mathrm{NaCl}$ solution) can be seen in Table 1. The data were similar in all five seed lots used, with low variation, thus fitting within the maximum acceptable variation range for the test, which is from 1 to 2 percentage points (Marcos-Filho, 1999). Differences above the tolerated could cause changes in the relation between degree and period of wetting process of seeds. This change would also cause differences in the intensity of deterioration during the aging period. Therefore, to analyze water content of a lot of seeds is essential to make a test more adequate.

The water content analyses of the seeds, after the accelerated aging period with saturated solution $(11 \% \mathrm{NaCl})$ and saturated saline solution $(40 \% \mathrm{NaCl})$, presented lower results in comparison with the traditional methodology. These results were also observed in seeds of similar size by Silva et al. (2010), in bermuda-grass seeds (Cynodon dactylon), and by Radke et al. (2016), in coriander seeds (Coriandrum sativum).

Using saline solution restricted water absorption by seeds. After $72 \mathrm{~h}$ of aging, seeds showed, in average, $20.1 \%, 11.5 \%$ and $9.2 \%$, in the traditional, USS and SSS methods, respectively.

The difference in the initial physiological quality of

Table 1. Water content (WC) initially and after obtaining three periods of accelerated aging, at $41{ }^{\circ} \mathrm{C}$, in amaranth seeds.

\begin{tabular}{ccccccccccc}
\hline & \multicolumn{9}{c}{ WC (\%) } \\
\cline { 2 - 10 } Lots & \multirow{2}{*}{ Initially } & \multicolumn{3}{c}{ TRAD $^{1}$} & \multicolumn{3}{c}{ USS $^{2}$} & \multicolumn{3}{c}{ SSS $^{3}$} \\
\cline { 3 - 10 } & & $24 \mathrm{~h}$ & $48 \mathrm{~h}$ & $72 \mathrm{~h}$ & $24 \mathrm{~h}$ & $48 \mathrm{~h}$ & $72 \mathrm{~h}$ & $24 \mathrm{~h}$ & $48 \mathrm{~h}$ & $72 \mathrm{~h}$ \\
\hline L1 & 13.1 & 18.7 & 19.0 & 20.2 & 10.2 & 10.1 & 11.3 & 8.2 & 8.4 & 9.1 \\
L2 & 13.5 & 18.9 & 19.1 & 20.1 & 10.5 & 10.2 & 11.4 & 8.8 & 8.1 & 9.2 \\
L3 & 13.0 & 18.5 & 18.8 & 20.0 & 10.5 & 10.4 & 11.4 & 8.3 & 8.2 & 9.2 \\
L4 & 13.1 & 18.6 & 18.8 & 20.1 & 10.9 & 10.4 & 11.4 & 8.3 & 8.3 & 9.4 \\
L5 & 13.2 & 18.7 & 18.9 & 20.1 & 10.7 & 10.3 & 11.7 & 8.5 & 8.4 & 9.3 \\
\hline
\end{tabular}

${ }^{1}$ Accelerated aging test following the traditional methodology with water;

${ }^{2}$ Accelerated aging test using unsaturated solution $(11 \% \mathrm{NaCl})$;

${ }^{3}$ Accelerated aging test using saturated saline solution $(40 \% \mathrm{NaCl})$. 
Table 2. Results of germination, first germination count and emergence in bed tests of five amaranth seeds lots.

\begin{tabular}{cccc}
\hline \multirow{2}{*}{ Lots } & $\mathrm{FGC}^{1}$ & Germination & Emergence \\
\cline { 2 - 4 } & $\%$ & $\%$ & $\%$ \\
\hline L1 & $97 \mathrm{a}^{2}$ & $98 \mathrm{a}$ & $79 \mathrm{c}$ \\
L2 & $91 \mathrm{~b}$ & $93 \mathrm{~b}$ & $73 \mathrm{~d}$ \\
L3 & $93 \mathrm{ab}$ & $94 \mathrm{ab}$ & $84 \mathrm{~b}$ \\
L4 & $98 \mathrm{a}$ & $99 \mathrm{a}$ & $88 \mathrm{a}$ \\
L5 & $75 \mathrm{c}$ & $76 \mathrm{c}$ & $60 \mathrm{e}$ \\
\hline CV (\%) & 6.1 & 6.5 & 10.5 \\
\hline
\end{tabular}

${ }^{1}$ First germination count of five amaranth seeds lots;

${ }^{2}$ Means followed by the same letter in the column do not differ from each other according to Tukey's test at 5\% probability.

amaranth seeds can be observed in Table 2. Lots 1, 2, 3 and 4 showed results of first germination count and germination tests above 90\%. However, lot 5 behaved differently and presented results lower than $80 \%$ in these tests.

Acording to the first germination count and germination tests, lots 1, 2, 3 and 4, despite their differences, presented close numerical values, with percentages of germination above $90 \%$. On the other hand, lot 5 exhibited values below $80 \%$, and it was the lot with worst performance in comparison with the others. If the difference in characteristics of the seeds lots was observed in the germination test, in which the conditions are optimal, the test itself would already be able to differentiate them. Araujo et al. (2011) also observed differences among lots already in the germination test, when evaluating six lots of mung-bean seeds. They verified that one of the lots presented difference in the percentage of germination, in relation to the others.

Amaranth seeds lots exhibited similar outcome concerning the differentiation in the emergence test, but lot 5 showed inferior results in comparison to the others. In general, the percentage of emergence was not high, which characterize the lots as of low or medium vigor.

When the results of the accelerated aging test of the five lots are examined, as shown in Table 3 , it can be verified by the traditional method that, over the periods of 24 and 48 hours, lots 1, 3 and 4 were similar to each other, but differed from lots 2 and 5. With the increase of the exposure time for 72 hours, lots 1, 2, 3 and 4 did not differ among them, and lot 5 presented lower physiological performance than the others.

In general, when using the method with unsaturated solution $(11 \% \mathrm{NaCl})$, regardless the period applied, lots 1,3 and 4 exhibited similar results, and lot 2 neither did nor differs from lot 5 in the periods of 24 and 48 hours, but there was a difference between these two lots in the period of accelerated aging of 72 hours.

In the saturate saline solution $(40 \% \mathrm{NaCl})$ method, lots showed results similar to those found when the unsaturated saline solution $(11 \% \mathrm{NaCl})$ was used in the periods of 24 and 48 hours. However, with 72 hours, lots 1, 2, 3, and 4 did not differ among them, whereas lot 5 exhibited inferior results.

Ranking seeds lots according to the accelerated aging test was verified for wheat (Ohlson et al., 2010), bermuda-grass (Silva et al., 2010), carrot, pea, beans and soybeans (ISTA, 2014).

The fact that the percentage of germination, after the accelerated aging test period, has augmented with the increasing in time of seed exposure to high humidity and temperature (Table 3), as occurs in the accelerated aging test and also in the saturated saline solution method, can be explained due to the occurrence of a secondary dormancy induced by the periods of 24 and 48 hours of high temperature and relative humidity.

The combination of factors, such as temperature,

Table 3. Results of accelerated aging test using different solutions - traditional method (water), saline solution ( $11 \% \mathrm{NaCl})$, concentrate saline solution $(40 \% \mathrm{NaCl})$; and three periods of exposure to the test, for amaranth seeds.

\begin{tabular}{|c|c|c|c|c|c|c|c|c|c|}
\hline \multirow{3}{*}{ Lots } & \multicolumn{9}{|c|}{ Vigor } \\
\hline & \multicolumn{3}{|c|}{ TRAD $^{1}$} & \multicolumn{3}{|c|}{$\mathrm{USS}^{2}$} & \multicolumn{3}{|c|}{$\mathrm{SSS}^{3}$} \\
\hline & $24 \mathrm{~h}$ & $48 \mathrm{~h}$ & $72 \mathrm{~h}$ & $24 \mathrm{~h}$ & $48 \mathrm{~h}$ & $72 \mathrm{~h}$ & $24 \mathrm{~h}$ & $48 \mathrm{~h}$ & $72 \mathrm{~h}$ \\
\hline $\mathrm{L1}$ & $96 \mathrm{a}^{4}$ & $97 \mathrm{a}$ & $96 \mathrm{a}$ & $97 \mathrm{a}$ & $96 \mathrm{a}$ & $95 \mathrm{ab}$ & $89 a b$ & $99 \mathrm{a}$ & $95 \mathrm{a}$ \\
\hline $\mathrm{L} 2$ & $69 \mathrm{~b}$ & $77 \mathrm{~b}$ & $92 \mathrm{a}$ & $63 \mathrm{c}$ & $85 \mathrm{bc}$ & $87 \mathrm{~b}$ & $78 \mathrm{bc}$ & $85 \mathrm{bc}$ & $91 \mathrm{a}$ \\
\hline L3 & $92 \mathrm{a}$ & $93 a$ & $94 \mathrm{a}$ & $90 \mathrm{ab}$ & $94 \mathrm{ab}$ & $95 \mathrm{ab}$ & $84 \mathrm{abc}$ & $96 a b$ & $97 \mathrm{a}$ \\
\hline $\mathrm{L} 4$ & $94 \mathrm{a}$ & $94 \mathrm{a}$ & $90 \mathrm{a}$ & $95 \mathrm{a}$ & $92 \mathrm{ab}$ & $98 \mathrm{a}$ & $96 \mathrm{a}$ & $96 \mathrm{ab}$ & $95 \mathrm{a}$ \\
\hline L5 & $69 \mathrm{~b}$ & $74 \mathrm{~b}$ & $74 \mathrm{~b}$ & $78 \mathrm{bc}$ & $75 \mathrm{c}$ & $70 \mathrm{c}$ & $69 \mathrm{c}$ & $73 \mathrm{c}$ & $72 \mathrm{~b}$ \\
\hline $\mathrm{CV}(\%)$ & 8.35 & 6.80 & 7.27 & 8.25 & 6.48 & 8.46 & 9.09 & 6.57 & 8.44 \\
\hline
\end{tabular}

${ }^{1}$ Accelerated aging test following the traditional methodology with water

${ }^{2}$ Accelerated aging test using unsaturated solution $(11 \% \mathrm{NaCl})$;

${ }^{3}$ Accelerated aging test using saturated saline solution $(40 \% \mathrm{NaCl})$.

${ }^{4}$ Means followed by the same letter in the column do not differ from each other according to Tukey's test at $5 \%$ probability. 
water availability, light and others, is directly related to the germination potential of a seed or seeds lot (Guillemin et al., 2013). In this sense, temperature may interfere both in overcoming the dormancy in some species, as well as in inducing a secondary dormancy (Taab and Andersson, 2009). Bastiani et al. (2015) evaluated seeds of barnyard grass submitted to light and temperature conditions, and found that germination was influenced by both parameters. Seeds in conditions of high or low temperatures can undergo metabolic changes, which affect the enzymatic expression responsible for the germination process (Mertz et al., 2009).

Another possible explanation is related to the presence or absence of certain microorganisms that, in an environment with high temperatures and humidity, may develop causing differences in results, which are often higher than in the germination test (Marcos-Filho, 1999).

The results of electrical conductivity of the five lots of amaranth seeds evaluated are presented in Table 4 .

In general, the results of electric conductivity test in amaranth seeds, for the lowest volume of water analyzed ( 25 $\mathrm{mL}$ ) and 100 seeds, showed data that resembled the separation of lots obtained in the emergence test (Table 4). By increasing the volume of water $(50 \mathrm{~mL})$ and using the lowest amount of seeds (100 seeds), there was similarity with the lot ranking obtained in the emergence test in the 4-hour period. This occurrence was also observed with the same volume of water, but with a larger number of seeds ( 150 seeds), for the periods of 6 and 24 hours.

In the electrical conductivity test, lot 5 presented higher levels of electrolyte leaching to the aqueous medium, which explains the low vigor already identified in the emergence test. This fact allowed the ranking of the lots, since the results could be compared with those of the emergence test. This similarity was found in the 6-hour period, in water volume and seed quantity of $25 \mathrm{~mL}$ and 100 seeds, respectively. Similarly, Vidigal et al. (2008) verified an adequate stratification of pepper seed lots, using $25 \mathrm{~mL}, 50$ seeds and 1-hour hydration period.

A test should provide results in a short time. Thus, it is

Table 4. Electrical conductivity $\left(\mu \mathrm{S} \cdot \mathrm{cm}^{-1} \cdot \mathrm{g}^{-1}\right)$ in five amaranth seeds lots as a function of the number of seeds, volume of water and periods of hydration.

\begin{tabular}{|c|c|c|c|c|c|c|c|c|c|c|}
\hline \multirow{3}{*}{ Lot } & \multicolumn{10}{|c|}{$25 \mathrm{~mL}$ of water } \\
\hline & \multicolumn{5}{|c|}{100 seeds } & \multicolumn{5}{|c|}{150 seeds } \\
\hline & $2 \mathrm{~h}$ & $4 \mathrm{~h}$ & $6 \mathrm{~h}$ & $8 \mathrm{~h}$ & $24 \mathrm{~h}$ & $2 \mathrm{~h}$ & $4 \mathrm{~h}$ & $6 \mathrm{~h}$ & $8 \mathrm{~h}$ & $24 \mathrm{~h}$ \\
\hline L 1 & $3.0 \mathrm{a}^{1}$ & $5.8 \mathrm{a}$ & $4.1 \mathrm{a}$ & $5.1 \mathrm{a}$ & $8.3 \mathrm{a}$ & $3.9 \mathrm{ba}$ & $4.6 \mathrm{a}$ & $6.3 \mathrm{a}$ & $6.5 \mathrm{a}$ & $8.1 \mathrm{a}$ \\
\hline L 2 & $7.4 \mathrm{~b}$ & $10.4 \mathrm{c}$ & $10.3 \mathrm{~b}$ & $13.0 \mathrm{~b}$ & $12.8 \mathrm{~b}$ & $2.8 \mathrm{a}$ & $8.0 \mathrm{c}$ & $9.5 \mathrm{~b}$ & $15.3 \mathrm{c}$ & $14.8 \mathrm{~b}$ \\
\hline L 3 & $8.9 \mathrm{~b}$ & $8.0 \mathrm{~b}$ & $12.7 \mathrm{c}$ & $15.2 \mathrm{~b}$ & $14.1 \mathrm{~b}$ & $5.7 \mathrm{c}$ & $7.6 \mathrm{c}$ & $10.8 \mathrm{cb}$ & $10.9 \mathrm{~b}$ & $14.4 \mathrm{~b}$ \\
\hline L 4 & $3.2 \mathrm{a}$ & $4.5 \mathrm{a}$ & $4.5 \mathrm{a}$ & $5.1 \mathrm{a}$ & $5.1 \mathrm{a}$ & $4.4 \mathrm{~b}$ & $5.9 \mathrm{~b}$ & $6.5 \mathrm{a}$ & $6.8 \mathrm{a}$ & $8.4 \mathrm{a}$ \\
\hline L 5 & $12.2 \mathrm{c}$ & $14.7 \mathrm{~d}$ & $16.6 \mathrm{~d}$ & $30.2 \mathrm{c}$ & $24.3 \mathrm{c}$ & $5.1 \mathrm{cb}$ & $4.1 \mathrm{a}$ & $11.7 \mathrm{c}$ & $16.3 \mathrm{c}$ & $27.9 \mathrm{c}$ \\
\hline $\mathrm{CV}(\%)$ & 16.4 & 13.5 & 8.1 & 15.7 & 12.0 & 15.1 & 10.0 & 8.4 & 13.7 & 13.2 \\
\hline \multirow{3}{*}{ Lot } & \multicolumn{10}{|c|}{$50 \mathrm{~mL}$ of water } \\
\hline & \multicolumn{5}{|c|}{100 seeds } & \multicolumn{5}{|c|}{150 seeds } \\
\hline & $2 \mathrm{~h}$ & $4 \mathrm{~h}$ & $6 \mathrm{~h}$ & $8 \mathrm{~h}$ & $24 \mathrm{~h}$ & $2 \mathrm{~h}$ & $4 \mathrm{~h}$ & $6 \mathrm{~h}$ & $8 \mathrm{~h}$ & $24 \mathrm{~h}$ \\
\hline L 1 & $2.2 \mathrm{a}$ & $1.3 \mathrm{a}$ & $2.1 \mathrm{a}$ & $1.0 \mathrm{a}$ & $2.4 \mathrm{a}$ & $2.4 \mathrm{a}$ & $1.9 \mathrm{a}$ & $2.2 \mathrm{a}$ & $2.2 \mathrm{a}$ & $3.3 \mathrm{a}$ \\
\hline L 2 & $3.3 \mathrm{ab}$ & $3.9 \mathrm{~b}$ & $3.8 \mathrm{ba}$ & $8.1 \mathrm{~b}$ & $10.2 \mathrm{c}$ & $7.5 \mathrm{c}$ & $2.5 \mathrm{a}$ & $3.9 \mathrm{~b}$ & $7.4 \mathrm{~b}$ & $8.7 \mathrm{~b}$ \\
\hline L 3 & $5.5 \mathrm{c}$ & $5.0 \mathrm{~b}$ & $5.4 \mathrm{~b}$ & $7.1 \mathrm{~b}$ & $5.9 \mathrm{~b}$ & $5.4 \mathrm{~b}$ & $4.2 \mathrm{~b}$ & $5.1 \mathrm{~b}$ & $4.9 \mathrm{a}$ & $7.6 \mathrm{~b}$ \\
\hline L 4 & $4.4 \mathrm{bc}$ & $4.5 \mathrm{~b}$ & $4.6 \mathrm{~b}$ & $6.2 \mathrm{~b}$ & $5.4 \mathrm{~b}$ & $3.9 \mathrm{a}$ & $5.0 \mathrm{~b}$ & $5.2 \mathrm{~b}$ & $5.6 \mathrm{a}$ & $7.2 \mathrm{~b}$ \\
\hline L 5 & $7.9 \mathrm{~d}$ & $10.3 \mathrm{c}$ & $11.1 \mathrm{c}$ & $13.8 \mathrm{c}$ & $15.9 \mathrm{~d}$ & $10.5 \mathrm{~d}$ & $8.9 \mathrm{c}$ & $10.2 \mathrm{c}$ & $13.6 \mathrm{c}$ & $13.4 \mathrm{c}$ \\
\hline $\mathrm{CV}(\%)$ & 20.0 & 15.0 & 22.2 & 13.9 & 19.0 & 10.1 & 14.9 & 14.3 & 13.4 & 18.8 \\
\hline \multirow{3}{*}{ Lot } & \multicolumn{10}{|c|}{$75 \mathrm{~mL}$ of water } \\
\hline & \multicolumn{5}{|c|}{100 seeds } & \multicolumn{5}{|c|}{150 seeds } \\
\hline & $2 \mathrm{~h}$ & $4 \mathrm{~h}$ & $6 \mathrm{~h}$ & $8 \mathrm{~h}$ & $24 \mathrm{~h}$ & $2 \mathrm{~h}$ & $4 \mathrm{~h}$ & $6 \mathrm{~h}$ & $8 \mathrm{~h}$ & $24 \mathrm{~h}$ \\
\hline L 1 & $0.4 \mathrm{a}$ & $0.4 \mathrm{a}$ & $0.4 \mathrm{a}$ & $1.4 \mathrm{a}$ & $0.7 \mathrm{a}$ & $1.7 \mathrm{a}$ & $0.6 \mathrm{a}$ & $1.5 \mathrm{a}$ & $1.2 \mathrm{a}$ & $2.0 \mathrm{a}$ \\
\hline L 2 & $3.5 \mathrm{~cd}$ & $2.7 \mathrm{bc}$ & $3.8 \mathrm{c}$ & $3.8 \mathrm{bc}$ & $5.0 \mathrm{bc}$ & $3.3 \mathrm{ab}$ & $3.0 \mathrm{c}$ & $3.6 \mathrm{~b}$ & $4.4 \mathrm{c}$ & $4.6 \mathrm{~b}$ \\
\hline L 3 & $2.8 \mathrm{bc}$ & $3.3 \mathrm{c}$ & $3.7 \mathrm{c}$ & $4.3 \mathrm{~cd}$ & $3.2 \mathrm{~b}$ & $4.2 \mathrm{~b}$ & $2.1 \mathrm{bc}$ & $3.6 \mathrm{~b}$ & $3.1 \mathrm{bc}$ & $4.7 \mathrm{~b}$ \\
\hline L 4 & $1.7 \mathrm{~b}$ & $2.3 \mathrm{c}$ & $1.7 \mathrm{~b}$ & $2.2 \mathrm{ab}$ & $5.6 \mathrm{c}$ & $2.0 \mathrm{a}$ & $1.7 \mathrm{ab}$ & $1.5 \mathrm{a}$ & $2.7 \mathrm{~b}$ & $4.0 \mathrm{~b}$ \\
\hline L 5 & $4.1 \mathrm{~d}$ & $4.6 \mathrm{~d}$ & $6.5 \mathrm{~d}$ & $5.8 \mathrm{~d}$ & $9.6 \mathrm{~d}$ & $7.6 \mathrm{c}$ & $4.6 \mathrm{~d}$ & $6.8 \mathrm{c}$ & $11.3 \mathrm{~d}$ & $10.4 \mathrm{c}$ \\
\hline $\mathrm{CV}(\%)$ & 26.5 & 18.1 & 21.8 & 27.8 & 21.3 & 24.9 & 26.0 & 20.3 & 15.9 & 16.3 \\
\hline
\end{tabular}

${ }^{1}$ Means followed by the same letter do not differ significantly from each other according to Tukey's test at $5 \%$ probability $(\leq 5 \%)$. 
important to use as little material as possible, and perform the test fast, but without altering the reliability of the results. The electrical conductivity test was efficient in separating lots of black oat seeds (Menezes et al., 2007), annual ryegrass (Lopes and Franke, 2010), beans, soybeans and pea (ISTA, 2014).

Values of correlation between seedlings emergence and the accelerated aging test and the electrical conductivity test were presented in Tables 5 and 6 , respectively.

The correlation data between the emergence and the accelerated aging test (Table 5) exhibited positive results, with $1 \%$ significance according to T-test, degree of association of 0.90 for the accelerated aging test with unsaturated solution $(11 \% \mathrm{NaCl})$ in the 72 -hours period, and correlation coefficient of $r=0.75$, both in the traditional accelerated aging test and in the one using saturated saline solution $(40 \% \mathrm{NaCl})$, in the same period ( 72 hours), being classified as a strong correlation according to Shimakura (2006). Ranking of lots was similar to one obtained in the emergence.

As for the correlation between amaranth seedlings emergence and electrical conductivity (Table 6), it can be noticed that, considering period of hydration, quantity of water and amount of seeds, the strongest correlations were observed in 8 hours, $25 \mathrm{~mL}$ and 100 seeds, and in the periods of 6 and 8 hours, with $75 \mathrm{~mL}$ of water and 150 seeds, with $r$ greater than 0.80 at $1 \%$ probability, indicating that the results were inversely proportional to those of the emergence test in field (Table 2), i. e., as the conductivity

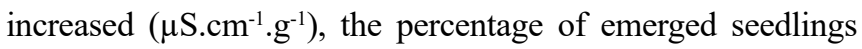
decreased. Although the periods of 6 and 8 hours, with the quantity of water of $75 \mathrm{~mL}$ and 150 seeds, presented close correlation, both with $\mathrm{r}=0.81$ at $1 \%$ probability, the vigor test must be attributed according to some principles, like uniformity, precision and speed. In this case, considering the cost of amaranth seeds, the most indicated is to use smaller quantities of seeds, tied to the shortest possible time, which justifies the speed of the results in a vigor test. Therefore, the period of 8 hours of hydration, $25 \mathrm{~mL}$ of water and 100 seeds, which also presented a close correlation of $r=0.87$, provided a consistent classification of the amaranth seeds lots.

The use of seeds with high physiological potential is directly related to the initial establishment, and also to the speed and uniformity of a plant stand in various environmental conditions. It will depend not only on the germinative power

Table 5. Coefficients of simple linear correlation (r) between accelerated aging and emergence tests in seedlings from seeds of five Amaranthus cruentus seeds lots.

\begin{tabular}{|c|c|c|c|c|c|c|c|c|c|}
\hline & \multicolumn{9}{|c|}{ Accelerated aging } \\
\hline & \multicolumn{3}{|c|}{ TRAD $^{1}$} & \multicolumn{3}{|c|}{$\mathrm{USS}^{2}$} & \multicolumn{3}{|c|}{$\mathrm{SSS}^{3}$} \\
\hline \multirow{2}{*}{ Value } & $24 \mathrm{~h}$ & $48 \mathrm{~h}$ & $72 \mathrm{~h}$ & $24 \mathrm{~h}$ & $48 \mathrm{~h}$ & $72 \mathrm{~h}$ & $24 \mathrm{~h}$ & $48 \mathrm{~h}$ & $72 \mathrm{~h}$ \\
\hline & $0.62^{*}$ & $0.66^{*}$ & $0.75^{*}$ & $0.48^{* *}$ & $0.65^{*}$ & $0.90^{*}$ & $0.67^{*}$ & $0.73^{*}$ & $0.75^{*}$ \\
\hline
\end{tabular}

${ }^{1}$ Accelerated aging test following the traditional methodology with water;

${ }^{2}$ Accelerated aging test using unsaturated solution $(11 \% \mathrm{NaCl})$;

${ }^{3}$ Accelerated aging test using saturated saline solution $(40 \% \mathrm{NaCl})$.

*Significant according to T-test at $1 \%$ probability;

**Significant according to T-test at $5 \%$ probability.

Table 6. Coefficients of simple linear correlation (r) between electrical conductivity and emergence in field tests of five lots of Amaranthus cruentus seeds with different levels of physiological quality.

\begin{tabular}{|c|c|c|c|c|c|c|c|c|c|}
\hline \multicolumn{10}{|c|}{$25 \mathrm{~mL}$ of water } \\
\hline \multicolumn{5}{|c|}{100 seeds } & \multicolumn{5}{|c|}{150 seeds } \\
\hline $2 \mathrm{~h}$ & $4 \mathrm{~h}$ & $6 \mathrm{~h}$ & $8 \mathrm{~h}$ & $24 \mathrm{~h}$ & $2 \mathrm{~h}$ & $4 \mathrm{~h}$ & $6 \mathrm{~h}$ & $8 \mathrm{~h}$ & $24 \mathrm{~h}$ \\
\hline$-0.53^{*}$ & $-0.32^{\mathrm{ns}}$ & $-0.52^{*}$ & $-0.87^{*}$ & $-0.45^{* *}$ & $0.15^{\mathrm{ns}}$ & $-0.09^{\mathrm{ns}}$ & $0.28^{\mathrm{ns}}$ & $0.43^{* *}$ & $-0.87^{*}$ \\
\hline \multicolumn{10}{|c|}{$50 \mathrm{~mL}$ of water } \\
\hline $2 \mathrm{~h}$ & $4 \mathrm{~h}$ & $6 \mathrm{~h}$ & $8 \mathrm{~h}$ & $24 \mathrm{~h}$ & $2 \mathrm{~h}$ & $4 \mathrm{~h}$ & $6 \mathrm{~h}$ & $8 \mathrm{~h}$ & $24 \mathrm{~h}$ \\
\hline$-0.33^{\mathrm{ns}}$ & $-0.48^{* *}$ & $-0.35^{\mathrm{ns}}$ & $-0.61^{*}$ & $-0.55^{*}$ & $-0.41^{* *}$ & $-0.58^{*}$ & $-0.26^{\mathrm{ns}}$ & $-0.77^{*}$ & $-0.56^{*}$ \\
\hline \multicolumn{10}{|c|}{$75 \mathrm{~mL}$ of water } \\
\hline $2 \mathrm{~h}$ & $4 \mathrm{~h}$ & $6 \mathrm{~h}$ & $8 \mathrm{~h}$ & $24 \mathrm{~h}$ & $2 \mathrm{~h}$ & $4 \mathrm{~h}$ & $6 \mathrm{~h}$ & $8 \mathrm{~h}$ & $24 \mathrm{~h}$ \\
\hline$-0.55^{*}$ & $-0.78^{*}$ & $-0.58^{*}$ & $-0.77^{*}$ & $-0.65^{*}$ & $-0.80^{*}$ & $-0.75^{*}$ & $-0.81^{*}$ & $-0.81^{*}$ & $-0.77^{*}$ \\
\hline
\end{tabular}

* Significant according to T-test at $1 \%$ probability;

**Significant according to $\mathrm{T}$-test at $5 \%$ probability.

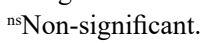


of the seeds, but also on their vigor. The speed of establishment and the uniformity of the stand guarantees a lower seed exposure to biotic and abiotic factors, which is important for the adequate development of the crop.

\section{Conclusions}

The accelerated aging test conducted at $41^{\circ} \mathrm{C}$ in a period of 72 hours with $\mathrm{NaCl}$ unsaturated saline solution is efficient in the classification of amaranth seed lots according to vigor levels.

The electrical conductivity test performed with a hydration period of 8 hours, $25 \mathrm{~mL}$ of water and 100 seeds showed relative efficiency in the classification of lots of amaranth seeds as to their physiological potential.

\section{Acknowledgements}

To the Coordenação de Aperfeiçoamento de Pessoal de Nível Superior (Capes) and the Brazilian Agricultural Research Corporation (Embrapa) due the financial support for research. Also, to professor Dr. Sabry G. Elias from Oregon State University for his guidance during his period of Special Visiting Researcher at Federal University of Pelotas.

\section{References}

ALVES, C.Z.; GODOY, A. R.; CANDIDO, A. C. S.; OLIVEIRA, N. C. Teste de condutividade elétrica na avaliação do potencial fisiológico de sementes de berinjela. Ciência Rural, v.42, n.6, p.975-980, 2012. $<$ http://www.scielo.br/scielo.php?script=sci_arttext\&pid=S010384782012000600004\&lng=en\&nrm=iso >. ISSN 1678-4596. http:// dx.doi.org/10.1590/S0103-84782012000600004.

ARAUJO, R.F.; ZONTA, J.B.; ARAÚJO, E.F.; DONZELES, S. M.; COSTA, G. M. Teste de condutividade elétrica para sementes de pinhão-manso (Jatropha curcas L.). Idesia (Arica), v.29, n.2, p.7986, 2012. http://dx.doi.org/10.4067/S0718-34292011000200010

ARAUJO, R. F.; ZONTA, J. B.; ARAUJO, E. F.; HEBERLE, E.; ZONTA, F. M. G. Teste de condutividade elétrica para sementes de feijão-mungo-verde. Revista Brasileira de Sementes, v.33, n.1, p.123130, 2011. http://dx.doi.org/10.1590/S0101-31222011000100014

AOSA. ASSOCIATION OF OFFICIAL SEED ANALYSTS. Seed vigor testing handbook. Lincoln: 2002. 105p. (Contribution, 32). http:// www.scielo.br/scielo.php?script=sci_nlinks\&ref=000063\&pid=S01013122201100010001400001\&lng=en

AVILA, P.F.V.; VILlELA, F.A.; AVILA, M.S.V. Teste de envelhecimento acelerado para avaliação do potencial fisiológico de sementes de rabanete. Revista Brasileira de Sementes, v.28, n.3, p. 52-58, 2006. http://www.scielo.br/scielo.php?script=sci_ arttext\&pid $=$ S0101-31222006000300008\&lng=en\&nrm=iso $>$.
BASTIANI, M.O.; LAMEGO, F.P.; NUNES, J. P.; MOURA, D. S.; WICKERT, R. J.; OLIVEIRA, J. I. Germinação de sementes de capimarroz submetidas a condições de luz e temperatura. Planta Daninha, v.33,n3,p.395-404,2015.http://www.scielo.br/scielo.php?script=sci arttext\&pid $=$ S010083582015000300395\&lng $=$ en\&nrm $=$ iso $>$. ISSN 0100-8358. http://dx.doi.org/10.1590/S0100-83582015000300002.

BERTOLIN, D. C.; SÁ, M. E.; MOREIRA, E. R.. Parâmetros do teste de envelhecimento acelerado para determinação do vigor de sementes de feijão. Revista Brasileira de Sementes, v. 33, n.1, p.104112, 2011. http://dx.doi.org/10.1590/S0101-31222011000100012

BRASIL. Ministério da Agricultura, Pecuária e Abastecimento. Regras para análise de sementes. Ministério da Agricultura, Pecuária e Abastecimento. Secretaria de Defesa Agropecuária. Brasília: MAPA-ACS, 2009. 395p. http://www.agricultura.gov.br/arq_editor/ file/2946_regras_analise_sementes.pdf

CASINI, P.; LA ROCCA, F. Amaranthus cruentus L. is suitable for cultivation in Central Italy: field evaluation and response to plant densities. Italian Journal of Agronomy, v. 9, n. 4, p. 166-175, 2014. http://dx.doi.org/10.4081/ija.2014.602

GUILLEMIN, J.P.; GAEDARIN, A.; GRANGER, S.; REIBEL, C.; MUNIER-JOLAIN, N.; COLBACH, N. Assessing potential germination period of weeds with base temperatures and base water potentials. Weed Research, v.53, n.1, p. 76-87, 2013. http:// onlinelibrary.wiley.com/doi/10.1111/wre.12000/abstract

ISTA. INTERNATIONAL RULES FOR SEED TESTING. Basseldorf, Switzerland, International Seed Testing Association, 303p. 2014.

LOPES, R.R.; FRANKE, L.B. Teste de condutividade elétrica para avaliação da qualidade fisiológica de sementes de azevém (Lolium multiflorum L.). Revista Brasileira de Sementes, v.32, n.1, p.123-130, 2010. <http:// dx.doi.org/10.1590/S0101-31222010000100014>

MACHADO, A.A.; CONCEIÇÃO, A.R. WinStat: sistema de análise estatística para windows. Universidade Federal de Pelotas, 2007. Disponível em $<$ http://www.ufpel.edu.br/ machado $>$

MARCOS-FILHO, J. Testes de vigor: importância e utilização. In: KRZYZANOWSKI, F.C.; VIEIRA, R.D.; FRANÇA-NETO, J.B. (Ed.). Vigor de sementes: conceitos e testes. Londrina: ABRATES, 1999. cap.3, p.1-24.

MENEZES, N.L.; GARCIA, D.C.; BAHRY, C.A.; MATTIONI, N.M. Teste de condutividade elétrica em aveia preta. Revista Brasileira de Sementes, v.29, n.2, p.138142, 2007. http://www.scielo.br/scielo.php?script=sci arttext\&pid=S010131222007000200019\&lng=en\&nrm=iso

MERTZ, L.C.; HENNING, F.A.; SOARES, R.C.; BALDIGA, R.F.; PESKE, F.; MORAES, D.M. Alterações fisiológicas em sementes de arroz expostas ao frio na fase de germinação. Revista Brasileira de Sementes, v.31, n.2, p.254-262, 2009. http://www.scielo.br/scielo.php?script=sci_ arttext\&pid=S010131222009000200031\&lng=en\&nrm=iso

MILANI, M.; LOPES, S. J. Teste de condutividade elétrica para avaliação do potencial fisiológico de sementes de canola. Ceres, v.59, n.3, p.374-379, 2015. http://dx.doi.org/10.1590/S0034737X2012000300012 
OHLSON, O.C.; KRZYZANOWSKI, F.C.; CAIEIRO, J.T.; PANOBIANCO, M. Teste de envelhecimento acelerado em sementes de trigo. Revista Brasileira de Sementes, v.32, n.4, p.118-124, 2010. http://dx.doi.org/10.1590/S0101-31222010000400013

RADKE, A.K.; REIS, B.B.; GEWEHR, E.; ALMEIDA, A.S.; TUNES, L.M.; VILLELA, F.A. Alternativas metodológicas do teste de envelhecimento acelerado em sementes de coentro. Ciência Rural, v.46, n.1, p.95-99, 2016. http://dx.doi.org/10.1590/0103$8478 \mathrm{cr} 20140188$

SANTOS, F.; TRANI, P. E.; MEDINA, P. F.; PARIS, J. J. D. Teste de envelhecimento acelerado para avaliação da qualidade de sementes de alface e almeirão. Revista Brasileira de Sementes, v. 33, p. 322323, 2011. http://www.scielo.br/pdf/rbs/v33n2/15.pdf

SHIMAKURA, S.E. Interpretação do coeficiente de correlação. 2006. <http://leg.ufpr.br/ silvia/CE003/node74.html> Accessed on: Jan. 2017.
SIlVA, C. B.; PIVETTA, K. F. L.; OlIVEIRA, C. A. V. M.; RODRIGUES, M. A.; VIEIRA, R. D. Teste de envelhecimento acelerado para avaliação do potencial fisiológico de sementes de grama-bermuda. Revista Brasileira de Sementes, v.32, n.2, p.102107, 2010. http://dx.doi.org/10.1590/S0101-31222010000200012

TAAB, A.; ANDERSSON, L. Seed dormancy dynamics and germination characteristics of Solanum nigrum. Weed Research, v. 49, n. 5, p. 490-498, 2009. http://onlinelibrary.wiley.com/ doi/10.1111/j.1365-3180.2009.00724.x/abstract

TEKRONY, D.M. Accelerated aging. In: VAN DE VENTER, H.A. (Ed.). Seed vigour testing seminar. Copenhagen: ISTA, 1995. p.53-72.

VIDIGAL, D. S.; LIMA, J.S.; BHERING, M.C.; DIAS, D.C.F.S. Teste de condutividade elétrica em sementes de pimenta. Revista Brasileira de Sementes, v.30, n.1, p.168-174, 2008. http://www. scielo.br/pdf/rbs/v30n1/a21v30n1.pdf 